\title{
COMPARISON OF ANALGESIA BY INTRAVENOUS BUTORPHANOL AND MEPERIDINE IN PATIENTS WITH POST-OPERATIVE PAIN
}

\author{
F.M. Galloway, J. Hrdlicka, M. Losada, R.J. Noveck, and F.S. Caruso
}

The NaRCotic analcesics and their antagonists form a series of drugs that range from the highly effective and highly addictive pure narcotic analgesic, morphine, to the pure narcotic antagonist naloxone, a drug devoid of analgesic activity. For many years, the objective of clinical research in the area of analgesia has been to identify analgesic agents with at least the efficacy of morphine but lacking its addictive and respiratory depressant properties. The rationale behind the search for a synthetic analgesic devoid of these properties is several-fold.

In an atmosphere where drugs of the narcotic class have a potential for abuse, the development of narcotic antagonist-analgesics reduces the liability of drug dependence. The antagonistic property inherent in these compounds appears to contribute to the prevention of addiction. ${ }^{1-4}$ In addition, with a shortage in the world supply of opium, there is a need for potent totally synthetic analgesics.

Completely synthetic compounds of the benzomorphan series such as cyclazocine and pentazocine have been developed. Even though these agents have a reduced liability for producing respiratory depression, constipation and urinary retention, they do exhibit psychomimetic effects which limit their clinical usefulness. Dobkin et al..$^{5,6}$ noted that pentazocine, although not nearly as psychogenic as cyclazocine, was much less potent on a unit weight basis than morphine. In addition, its efficacy in the treatment of severe post-operative pain was limited by the relatively high incidence of side effects encountered at doses required to produce adequate pain relief.

One approach to the solution of the problem has been the development of synthetic narcotic antagonist analgesics in the morphinan series. In 1972, Monkovic ${ }^{7,8}$ reported the total synthesis of butorphanol tartrate (levo-N-cyclobutylmethyl-314- $\beta$ dihydroxymorphinan). Figure 1 illustrates the structural formulae of butorphanol, meperidine, morphine and naloxone for comparison. Although it bears a structural resemblance to morphine and naloxone, the pharmacological profile of butorphanol is different. The results from animal studies indicate that the analgesic activity of butorphanol is four times that of morphine and 30 times that of $d l$-pentazocine. ${ }^{9,10}$ In addition, butorphanol is equivalent to nalorphine and 30 times more potent than pentazocine as a narcotic antagonist. Butorphanol also has potent antitussive properties in animals, ${ }^{11}$ being 20 times more potent than codeine by oral administration. Pircio, et al. ${ }^{10}$ have demonstrated that butorphanol has a lower physical dependence liability than pentazocine employing the mouse jump-

F.M. Galloway, M.D., Director, Department of Anesthesiology, Denver General Hospital, Denver, Colorado. J. Hrdlicka, M.D., Research Fellow, Department of Anesthesiology, Denver General Hospital, Denver, Colorado. M. Losada, B.S., R.J. Noveck, Ph.D., and F.S. Caruso, Ph.D., Medical Research Division, Bristol Laboratories, Syracuse, New York. 
<smiles>CCCOC(=O)C1(c2ccccc2)CCN(C)CC1</smiles><smiles>CN1CCC23c4c(ccc(O)c4C1C=CC2O)CCN3C</smiles>

Morphine<smiles>C=CCN1CCc2ccc(O)c3c2C2(CC3)C(O)CCC(=O)C12</smiles>

Naloxone

Ficure 1. Chemical formulae of butorphanol, meperidine, morphine and naloxone.

ing test and Swain, Villarreal and Seevers ${ }^{12}$ reported that butorphanol has a relatively limited liability for producing physical dependence in the rhesus monkey. Additional studies in man conducted at the Addiction Research Center in Lexington, Kentucky have confirmed these observations. ${ }^{13}$

Some clinical studies comparing the post-operative analgesic activity of butorphanol with those of morphine $e^{5,25}$ and pentazocine ${ }^{6}$ have also been reported. Butorphanol has been found to provide rapid pain relief with minimal side effects. For several years it has been our practice to administer intravenous meperidine as the post-operative analgesic. Therefore, to evaluate this new analgesic more fully, intravenous doses of butorphanol tartrate $(0.5 \mathrm{mg}, 1.0 \mathrm{mg}$ and $2.0 \mathrm{mg})$ were compared with intravenous doses of meperidine hydrochloride (20 mg and $40 \mathrm{mg}$ ) in a double blind study using post-operative in-patients with moderate to severe pain.

\section{Materials and Methods}

Signed informed consent was obtained from patients within 24 hours of major operations so that a sufficient number could be entered into the study. Patients with liver, renal or haematological disease, females of childbearing age, minors and patients with a history of tolerance of or dependence on narcotic drugs were excluded from the study. All 126 patients entered into the study were evaluated as being able to communicate their pain sensations to the observer.

Pre-operative medication usually consisted of a tranquilizer, a hypnotic, and a drying agent. In 116 patients, following induction with sodium thiamylal, anaesthesia was provided by a combination of nitrous oxide-oxygen and either halo- 
thane or enflurane. The remaining ten patients included five who had regional anaesthesia, four who had balanced anaesthesia (including fentanyl) and one who had ketamine. Postoperatively single intravenous doses of either butorphanol tartrate $(0.5 \mathrm{mg}, 1.0 \mathrm{mg}$ or $2 \mathrm{mg}$ expressed as salt) or meperidine hydrochloride ( 20 $\mathrm{mg}$ or $40 \mathrm{mg}$ expressed as salt) were administered as part of this investigation. The test drugs were provided in identical vials which were numbered consecutively and assigned to the patients in the order of their entrance into the study.

The test agents were evaluated post-operatively in the recovery room. When a patient complained of pain, the degree was graded as either severe (3), moderate (2), or slight (1). Patients complaining of moderate or severe pain were assigned a patient number and then $1 \mathrm{ml}$ of the contents of the vial with the corresponding number was administered intravenously.

After medication the patient was observed for a period of four hours or until further analgesia was required. The severity of pain was recorded at half, one, two, three and four hours following medication. In addition, the degree of pain relief was evaluated as either no relief (0), slight (1), moderate (2), good (3), or complete (4). The difference between the initial pain intensity score and those at each observation period provided an additional index of drug effectiveness and was designated as the pain intensity difference (PID). If a patient requested and received additional pain medication prior to the end of the four-hour study period, the pain intensity was considered to be severe (3) and the pain relief score to be 0 for all subsequent observation periods. All side effects reported by the patients or noted by the observer were recorded.

On completion of the study all the information was tabulated, the medication was decoded, and the data were statistically analyzed. Since one patient was returned to the operating room, the data from only 125 patients were included in the analysis. Values examined included (1) pain intensity scores, (2) pain relief scores, (3) pain intensity differences. These were analyzed by a modified computer program for the parallel-line assay method as described by Finney and others. $^{14,15}$ Additional analyses included: (1) one-way analysis of variance, (2) linear dose-response regressions, (3) Duncan's New-multiple Range Test

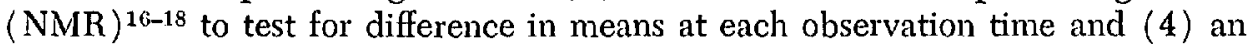
estimate of the potency of butorphanol tartrate as compared to that of meperidine hydrochloride.

\section{Results}

A demographic analysis of the patient population is indicated in Table 1 . The patients included in the statistical analysis ranged in age from 18 to 72 years and ranged in weight from 85 to 220 pounds ( 39 to $100 \mathrm{~kg}$ ). Sex distribution was 58 males and 67 females. In all groups except those of the high doses of butorphanol and meperidine, the distribution of male to female patients was similar. In these two groups, there were at least twice as many males as there were females. Also included in Table $I$ is a listing of the patients' initial pain intensity and the number of patients who needed further medication at various time intervals. With regard to the initial pain intensity, 82 patients suffered from severe pain while 43 patients had moderate pain before receiving the study medication. An indication 
GALLOWAY, et al.: EVALUATION OF BUTORPHANOL

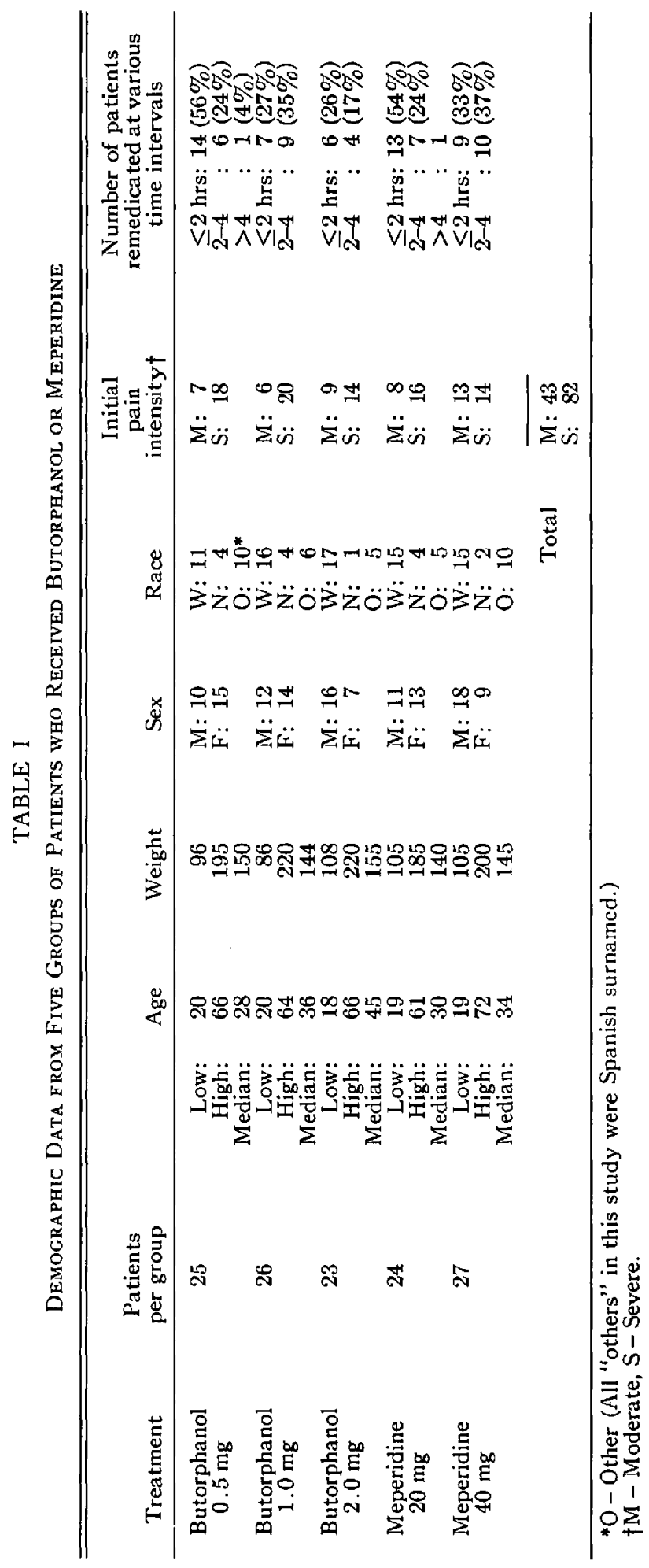


CANADIAN ANAESTHETISTS' SOCIETY JOURNAL

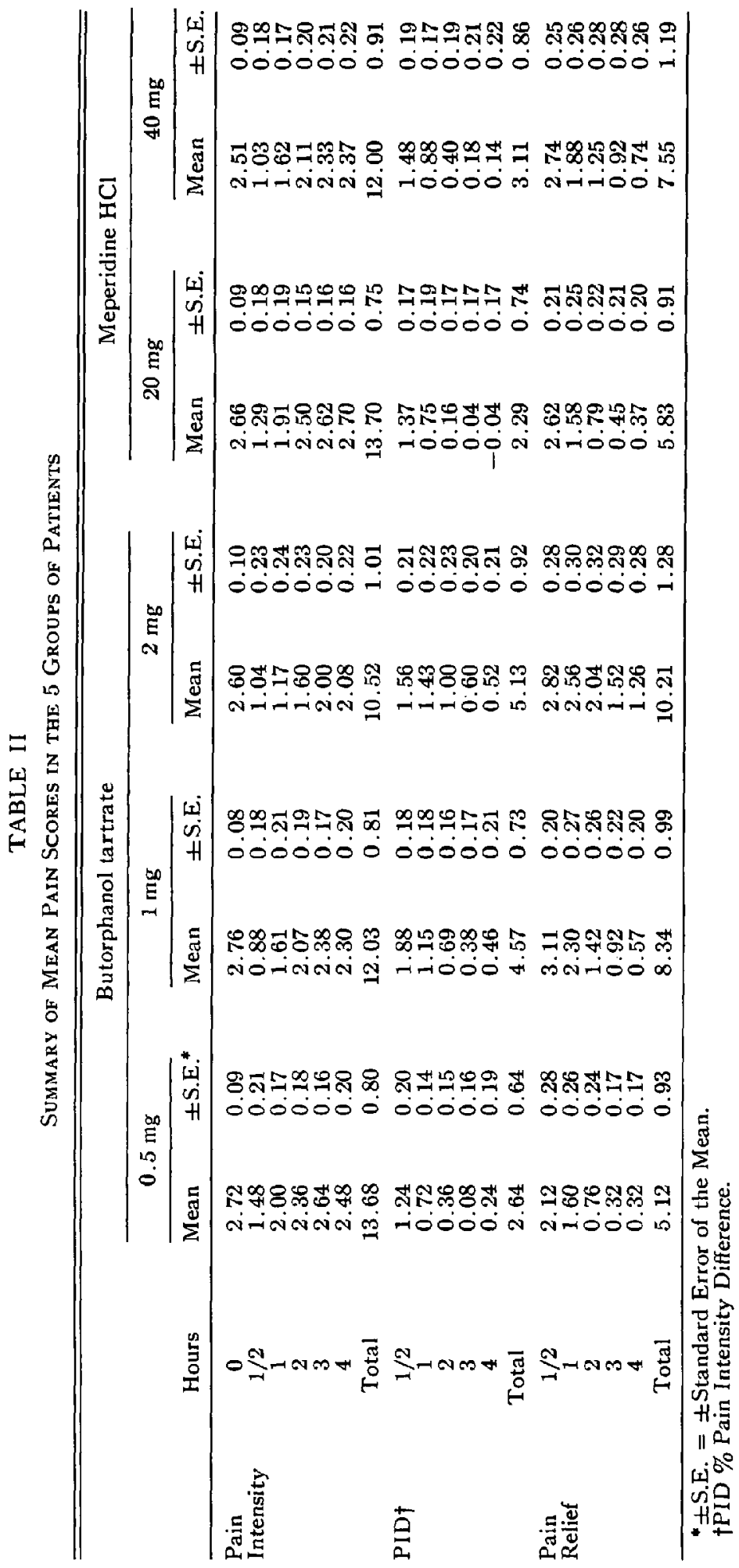


TABLE III

Potency Ratio of Butorphanol Relative to MEPERIDINE WITH $95 \%$ CONFIDENCE Limits

\begin{tabular}{lccr}
\hline \hline \multicolumn{1}{c}{ Variable } & $\begin{array}{c}\text { Potency } \\
\text { ratio }\end{array}$ & LCL* & UCL ${ }^{*}$ \\
\hline 1-Hour Response & & & \\
Pain Intensity Score & 38.9 & 19.1 & 123.0 \\
Pain Intensity Difference & 53.7 & 25.4 & 556.9 \\
Pain Relief & 54.9 & 25.4 & 770.4 \\
2-hr sums & 36.5 & 17.0 & 112.9 \\
Pain Intensity Score & 59.7 & 27.0 & $1,754.8$ \\
Pain Intensity Difference & 43.3 & 22.2 & 149.9 \\
Pain Relief & 39.5 & 18.9 & 138.6 \\
4-hr sums & 66.5 & 28.5 & $16,468.3$ \\
Pain Intensity Score & 40.4 & 22.5 & 99.0 \\
Pain Intensity Difference & & & \\
Pain Relief & & & \\
\hline *Lower confidence limit. & & & \\
†Upper confidence limit. & &
\end{tabular}

of the duration of action can be qualitatively obtained from the remedication data. The lowest rate of remedication ( 43 per cent) occurred in the butorphanol tartrate $2.0 \mathrm{mg}$ group, while the highest remedication rate ( 83 per cent) occurred in the group receiving meperidine $20 \mathrm{mg}$. These data also indicate that the duration of action butorphanol $0.5 \mathrm{mg}$ and meperidine $20 \mathrm{mg}$ was less than or equal to two hours. However, at the intermediate and high doses of butorphanol tartrate $(1 \mathrm{mg}$ and $2 \mathrm{mg}$ ) and at the high dose of meperidine hydrochloride $(40 \mathrm{mg})$, the duration was between two and four hours. Butorphanol $2 \mathrm{mg}$ produced the longest duration of action when compared with the other treatments included in the study.

The mean and standard errors for pain intensity, pain intensity difference (PID) and pain relief scores for each group is summarized in Table II and graphically represented in Figure 2. It is quite clear from these results that the peak response in each case occurred at the half-hour observation period. The statistical analyses (Duncan's NMR) indicate that at most of the time intervals there were no statistically significant differences between the responses to butorphanol tartrate $0.5 \mathrm{mg}$ and $1.0 \mathrm{mg}$ as compared with those to meperidine hydrochloride $20 \mathrm{mg}$ and $40 \mathrm{mg}$ respectively. Yet the responses observed following the administration of butorphanol $2.0 \mathrm{mg}$ was significantly greater $(\mathrm{p}<0.05)$ than the responses observed with the low dose of either medication.

Employing the parallel line bioassay for estimating the analgesic potency between these drugs, it can be observed (Table III) that butorphanol was approximately 40 to 50 times more potent than meperidine. These data demonstrate the high analgesic effectiveness of butorphanol. It should be pointed out, however, that the upper confidence limits for the pain intensity differences are of such an extreme magnitude that these results must be interpreted cautiously. In earlier studies in $\operatorname{man}^{5,25}$ butorphanol tartrate was demonstrated to be at least five times more potent than morphine sulfate which in turn has been reported to be at least eight to ten times more potent than meperidine. ${ }^{19}$ Therefore, by extrapolation, the butorphanol:meperidine potency ratio derived from the present study is in agreement with these data and would appear to be accurate. 
MEAN PAIN INTENSITY SCORE \pm S.E.M

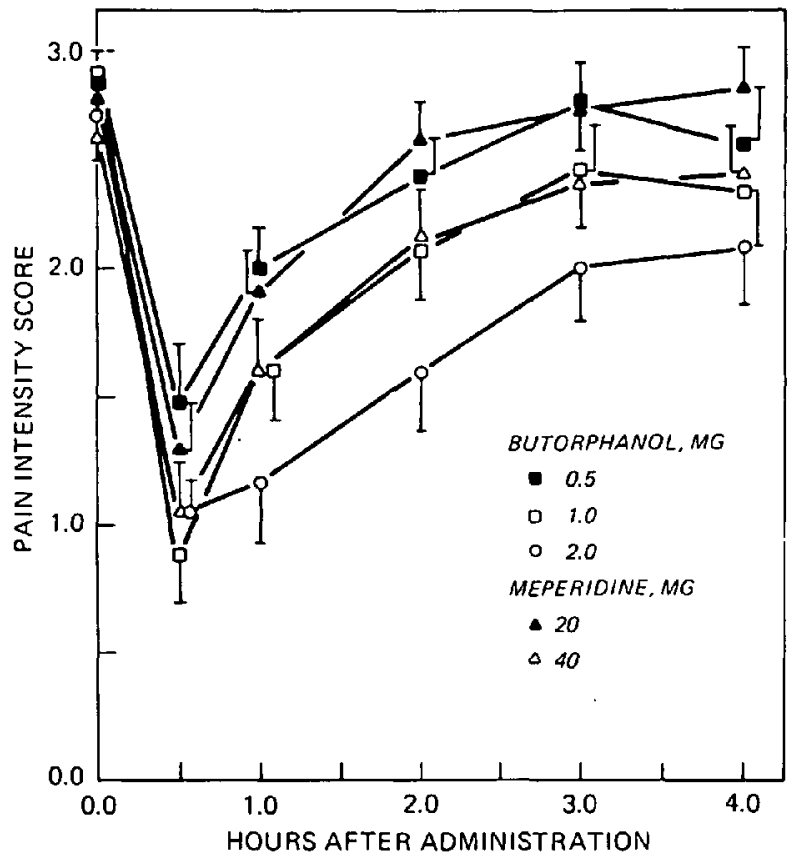

(a)

MEAN PAIN INTENSITY DIFFERENCE \pm S. E.M.

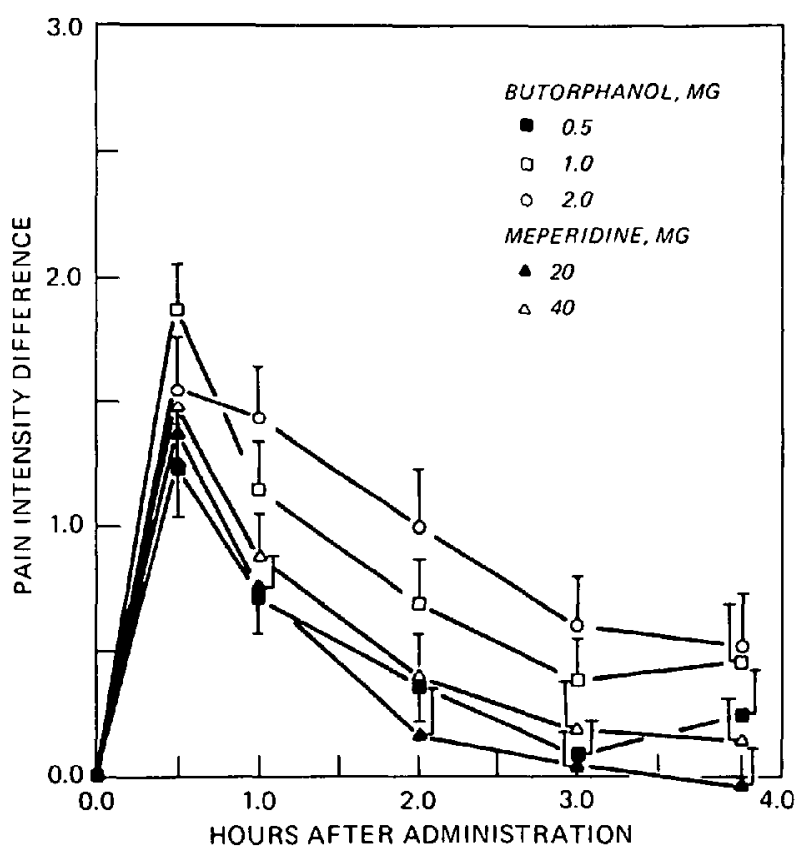

(b) 


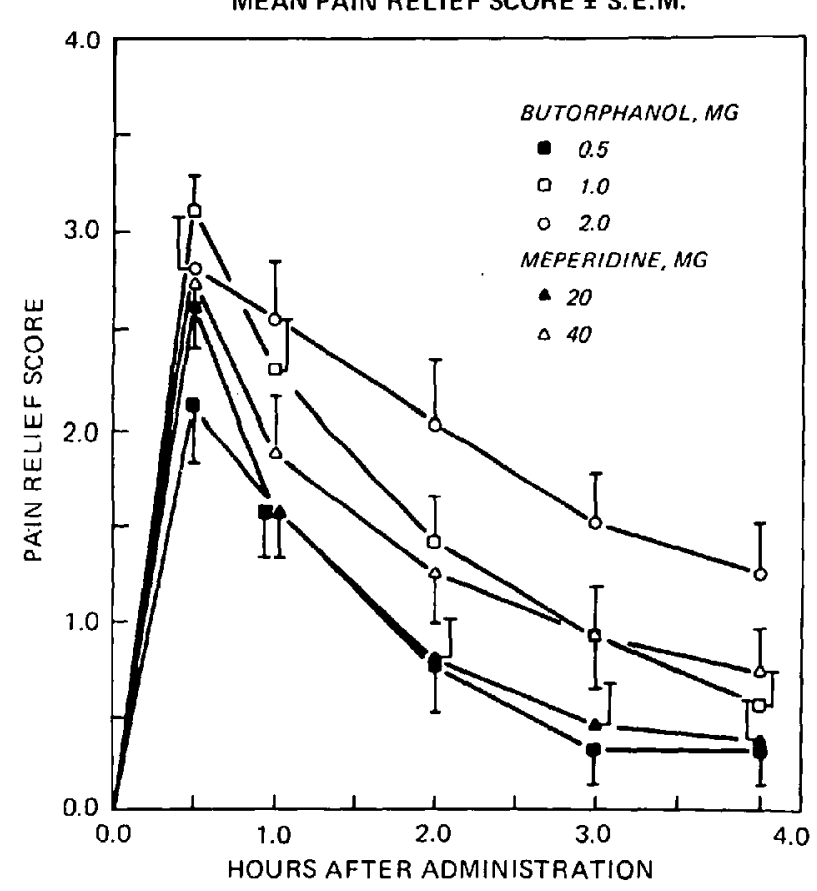

(c)

Figure 2 $(a, b, c)$. Graphic representation of pain scores in response to butorphanol tartrate $0.5 \mathrm{mg}, 1.0 \mathrm{mg}$, and $2.0 \mathrm{mg}$ and meperidine hydrochloride $20 \mathrm{mg}$ and $40 \mathrm{mg}$.

Table IV lists side-effects and their incidence. A comparison of the test groups with respect to the incidence and type of side effects reveals that the largest dose of butorphanol tartrate $(2.0 \mathrm{mg})$ produced the greatest incidence of drowsiness ( 39 per cent) which was the most common side effect in each test group. The incidence of other side effects was relatively low and there appeared to be no major differences among the groups with regard to the onset (usually 30 minutes post-treatment) and duration (usually 2 hours) of these side effects. In addition, one patient who received butorphanol $0.5 \mathrm{mg}$ and who was given meperidine 50 $\mathrm{mg}$ six hours later went into respiratory arrest and coma and was unresponsive to naloxone. Since this reaction occurred several hours following the lowest dose of butorphanol and immediately following meperidine, the event was not attributed to butorphanol. Another patient complained of dizziness, weakness and nausea after receiving meperidine two hours after an initial dose of meperidine $40 \mathrm{mg}$. These side effects were not included in Table IV. Both butorphanol and meperidine were tolerated and no local tissue reactions occurred.

\section{Discussion}

The difficulty of evaluating and quantitating pain is well known. Extensive reports have appeared in the literature evaluating the subjective responsiveness to pain and analgesics. ${ }^{20-23}$ Unlike experimental pain studies in normal volunteers 
TABLE IV

Summary of Side Effects Onserved After The Administration of Each Test Agent

\begin{tabular}{|c|c|c|c|c|}
\hline Treatment group & $\begin{array}{l}\text { Number of } \\
\text { patients }\end{array}$ & Side effects & Occur. & $\begin{array}{c}\text { Total } \\
\text { no. of } \\
\text { patients }\end{array}$ \\
\hline $\begin{array}{l}\text { Butorphanol } \\
\quad \text { tartrate } 0.5 \mathrm{mg}\end{array}$ & 26 & $\begin{array}{l}\text { Drowsy } \\
\text { Nausea } \\
\text { Resp. depression } \\
\text { No side effects }\end{array}$ & $\begin{array}{l}6 \\
1 \\
1\end{array}$ & $\begin{array}{c}3(12 \%) \\
1(4 \%) \\
1(4 \%) \\
21(81 \%)\end{array}$ \\
\hline $\begin{array}{l}\text { Butorphanol } \\
\text { tartrate } 1 \mathrm{mg}\end{array}$ & 26 & $\begin{array}{l}\text { Drowsy } \\
\text { Nausea } \\
\text { CNS depression } \\
\text { Calming } \\
\text { No side effects }\end{array}$ & $\begin{array}{r}11 \\
9 \\
1 \\
4\end{array}$ & $\begin{array}{l}3(11 \%) \\
2(8 \%) \\
1(4 \%) \\
2(8 \%) \\
19(73 \%)\end{array}$ \\
\hline $\begin{array}{l}\text { Butorphanol } \\
\text { tartrate } 2 \mathrm{mg}\end{array}$ & 23 & $\begin{array}{l}\text { Drowsy } \\
\text { Calming } \\
\text { Disoriented } \\
\text { No side effects }\end{array}$ & $\begin{array}{r}23 \\
1 \\
2\end{array}$ & $\begin{array}{c}9(39 \%) \\
1(4 \%) \\
1(4 \%) \\
12(52 \%)\end{array}$ \\
\hline $\begin{array}{l}\text { Meperidine } \\
\mathrm{HCl} 20 \mathrm{mg}\end{array}$ & 24 & $\begin{array}{l}\text { Nausea } \\
\text { Erythema } \\
\text { Dec. pulse } \\
\text { Urticaria } \\
\text { No side effects }\end{array}$ & $\begin{array}{l}1 \\
2 \\
1 \\
2\end{array}$ & $\begin{array}{c}1(4 \%) \\
1(4 \%) \\
1(4 \%) \\
2(8 \%) \\
19(79 \%)\end{array}$ \\
\hline $\begin{array}{l}\text { Meperidine } \\
\text { HCl } 40 \mathrm{mg}\end{array}$ & 27 & $\begin{array}{l}\text { Drowsy } \\
\text { Nausea } \\
\text { N \& V } \\
\text { Dizzy } \\
\text { Weakness } \\
\text { No side effects }\end{array}$ & $\begin{array}{r}11 \\
3 \\
1 \\
3 \\
3\end{array}$ & $\begin{array}{c}4(15 \%) \\
1(4 \%) \\
1(4 \%) \\
1(4 \%) \\
1(4 \%) \\
21(78 \%)\end{array}$ \\
\hline
\end{tabular}

who serve as their own controls, all variables cannot be eliminated when studying analgesics in the post-operative patient. For instance, the quality of post-operative pain varies considerably from patient to patient due to several factors, such as age, sex, the surgical procedure, the physician-patient relationship and the psychological makeup of the patient. With regard to this last factor, the patient's reaction to illness or injury and the impact that it has on his life situation are additional contributing factors.

For these reasons, an attempt was made to eliminate at least one variable by having all pain evaluations recorded by one trained observer. In addition, the premedication and anaesthetic techniques were for the most part similar. Patients undergoing major abdominal or major orthopedic procedures were selected for this study since it is after these operations that many patients experience moderate to severe pain.

Since it is our customary practice to use small intravenous doses of meperidine in the recovery room, it was not surprising to us that a high percentage of patients receiving the low dose of both test agents requested additional medication. The smaller butorphanol tartrate doses $(0.5 \mathrm{mg}$ and $1.0 \mathrm{mg})$ and all meperidine doses $(20 \mathrm{mg}$ and $40 \mathrm{mg}$ ) produced adequate analgesia with approximately a two-hour duration of action. The largest dose of butorphanol tartrate $(2.0 \mathrm{mg})$ produced analgesia of longer duration and produced somewhat more sedation.

It was also of interest that, with the exception of one patient who received 0.5 $\mathrm{mg}$ of butorphanol tartrate, no clinically significant post-operative respiratory 
GALLOWAY, et al.: EVALUATION OF BUTORPHANOL

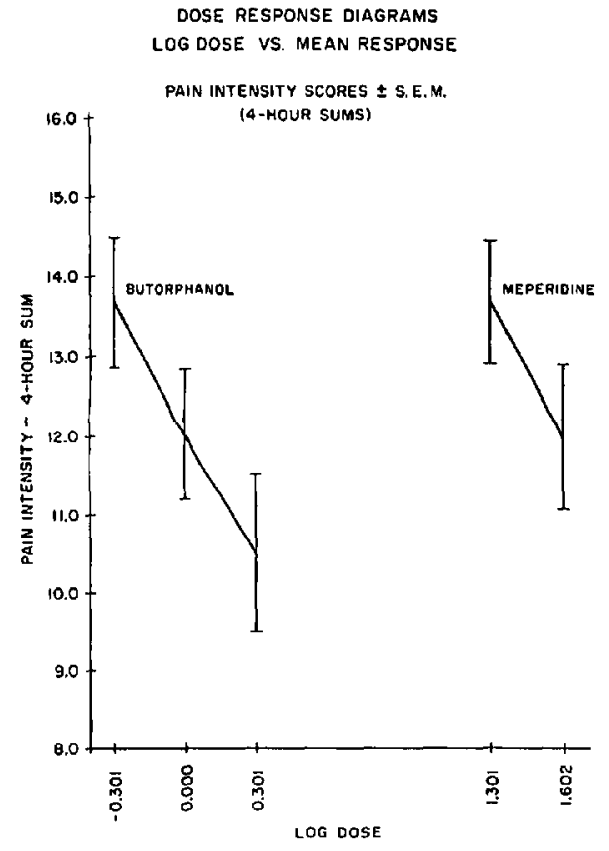

(a)

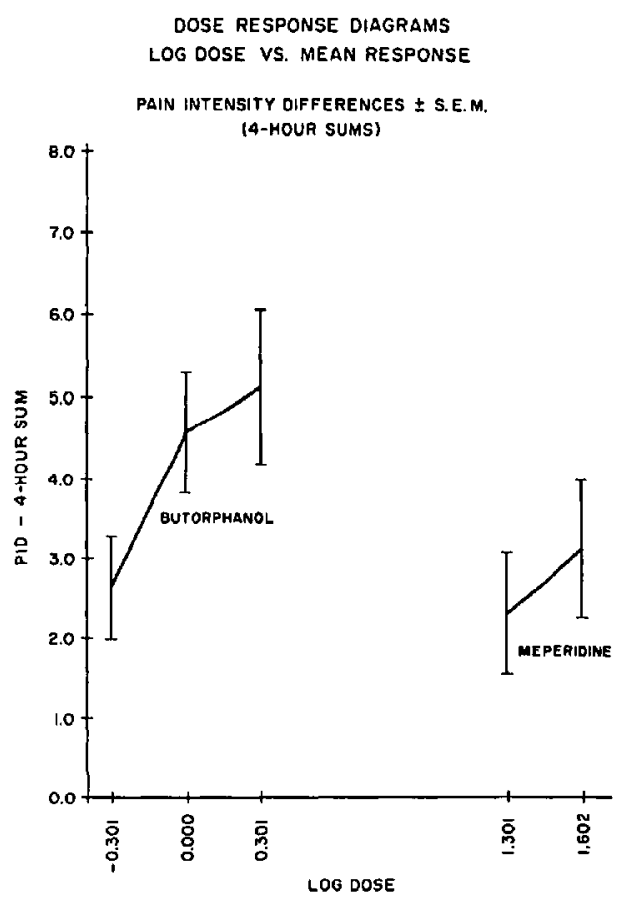

(b)

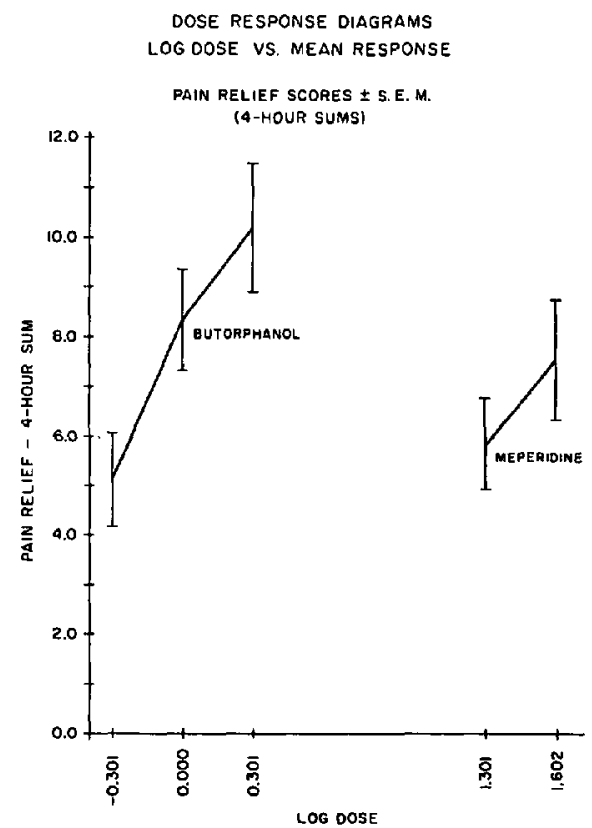

(c)

FIGURE $3(a, b, c)$. Graphic representation of the four-hour sums of the pain scores (log dose vs mean response). 
depression occurred in any patient. In a previous study evaluating the effect of butorphanol in normal volunteers, large intravenous doses (2.0 and $4.0 \mathrm{mg}$ ) were demonstrated not to depress respiration significantly more than morphine sulfate $10 \mathrm{mg} .{ }^{24}$ In addition, morphine $20.0 \mathrm{mg}$ produced a further dose-related respiratory depression, whereas the effect of butorphanol $4.0 \mathrm{mg}$ appeared to plateau and did not significantly produce more depression than either the $2.0 \mathrm{mg}$ dose of butorphanol or the $10 \mathrm{mg}$ dose of morphine.

In the present study, aside from the high incidence of sedation observed, other reported side effects were relatively minor. These results indicate that butorphanol is a safe and effective analgesic. Only through additional clinical trials in a larger population of patients will the clinical usefulness of butorphanol tartrate be completely established. If future studies substantiate our findings and further demonstrate that butorphanol has low addiction liability without adverse effects on the cardiovascular and respiratory systems, then it may find a place in modern medicine.

\section{Summary and Conclusion}

Intravenous doses of butorphanol tartrate $(0.5 \mathrm{mg}, 1.0 \mathrm{mg}$ and $2.0 \mathrm{mg})$ and meperidine hydrochloride $(20 \mathrm{mg}$ and $40 \mathrm{mg}$ ) were compared under controlled conditions employing a double blind study design. Informed consent was obtained from all post-operative patients suffering from moderate to severe pain who participated in this study. Approximately 25 patients were included in each group. The data from 125 patients were subjected to statistical analysis. The results indicated that butorphanol is approximately 40 to 50 times more potent than meperidine. In addition, at most of the time intervals, there were no statistically significant differences between the responses to butorphanol $0.5 \mathrm{mg}$ and $1 \mathrm{mg}$ and meperidine $20 \mathrm{mg}$ and $40 \mathrm{mg}$; but the response to butorphanol $2 \mathrm{mg}$ was significantly $(p<0.05)$ better than the low dose of each agent. The low doses of butorphanol $(0.5 \mathrm{mg})$ and meperidine $(20 \mathrm{mg}$ ) appear to have an effective duration of action of less than two hours. The larger doses (butorphanol $1.0 \mathrm{mg}$ and $2.0 \mathrm{mg}$ and meperidine $40 \mathrm{mg}$ ) appeared to produce a two- to four-hour duration of action. The largest butorphanol dose $(2.0 \mathrm{mg})$ appeared to produce the longest duration of action.

A comparison of the test groups with respect to the incidence and type of side effects showed that butorphanol $2.0 \mathrm{mg}$ produced a greater incidence of drowsiness (39 per cent). The overall incidence of drowsiness for patients receiving either the $0.5 \mathrm{mg}$ or $1.0 \mathrm{mg}$ dose of butorphanol was 12 per cent, as compared with an 8 per cent overall incidence in the meperidine group. The incidence of other side effects was relatively low in all test groups. No significant differences were noted among the groups with regard to the onset (usually $\leqslant 30$ minutes posttherapy) or the duration (usually $\leqslant 2$ hours) of side effects. Butorphanol appears to be a safe and effective analgesic for the relief of moderate to severe postoperative pain.

\section{RÉsuMé}

Cent vingt-cinq opérés consentants ont fait l'objet d'une étude à double insu 
comparant les effets du tartrate de butorphanol et de la mépéridine, devant une douleur post-opératoire variant de modérée à intense. Aux fins de cette étude, les malades ont été divisés en cinq groupes. Selon qu'ils appartenaient à l'un ou l'autre des groupes, ils ont reçu une dose intraveineuse de 0.5 , de 1.0 ou de $2.0 \mathrm{mg}$ de tartrate de butorphanol; ou encore, une dose intra-veineuse de 20 ou de $40 \mathrm{mg}$ de mépéridine.

Les résultats indiquent que la puissance du butorphanol est de 40 à 50 fois plus grande que celle de la mépéridine. La différence entre les effets des doses de 0.5 , de 1.0 et de $2.0 \mathrm{mg}$ de butorphanol et celle de doses de $40 \mathrm{mg}$ de mépéridine n'étaient pas significatives. La réponse à une dose de $2 \mathrm{mg}$ de butorphanol était plus grande $(\mathrm{p}<0.05)$ que celle observée après une dose de $0.5 \mathrm{mg}$ de butorphanol ou de $20 \mathrm{mg}$ de mépéridine.

La durée d'action de $0.5 \mathrm{mg}$ de butorphanol et de $20 \mathrm{mg}$ de mépéridine est d'environ 2 heures, alors que $40 \mathrm{mg}$ de mépéridine, ainsi que 1 ou $2 \mathrm{mg}$ de butorphanol ont un effet de 2 à 4 heures. C'est la dose de $2 \mathrm{mg}$ de butorphanol qui semble avoir l'effet le plus prolongé.

Une étude comparative des effets secondaires a révélé que $2 \mathrm{mg}$ de butorphanol produisaient plus de somnolence ( 39 pour cent) qu'une dose de 0.5 ou de $1 \mathrm{mg}$ de cet agent ( 12 pour cent), ou qu'une dose de mépéridine ( 8 pour cent). Les autres effets secondaires étaient relativement rares dans tous les groupes étudiés. On n’a pas noté de différence significative entre les groupes en regard du début $(\leqslant 30$ minutes) ou de la durée ( $\leqslant 2$ heures) des effets secondaires observés.

Le butorphanol nous apparaît un analgésique sur et efficace pour le soulagement de douleurs post-opératoires modérées ou intenses.

\section{ACKNOWLEDGMENTS}

The authors appreciate the assistance in this study of Bristol Laboratories, who also supplied the blinded vials, and the Mead Johnson Research Center. The authors would also like to thank Dr. J.A. Aldrete for his assistance in preparation of the manuscript.

\section{REFERENCES}

1. Lasagna, L. \& Beecher, H.K. The analgesic effectiveness of nalorphine and nalorphinemorphine combinations in man. J. Pharmacol. Exp. Ther. 112:356 (1954).

2. Harris, L.S. \& Pierson, A.K. Some narcotic antagonists in the benzomorphan series. J. Pharmacol. Exp. Ther. 143: 141 (1964).

3. Gordon, R.A. \& Moran, J.H. Studies of pentazocine (WIN 20, 228). 1. Evaluation as an analgesic in post-operative patients. Can. Anaesth. Soc. J. 12:331 (1965).

4. JAsinski, D.R., MARTIN, W.R., \& HoEldTKE, R.D. Effect of short- and long-term administration of pentazocine in man. Clin. Pharmacol, Ther. 11: 385 (1970).

5. Dobkin, A.B., Eamkaow, S., Zak, S., \& Canuso, F.S. Butorphanol: a double-blind evaluation in post-operative patients with moderate or severe pain. Can. Anaesth. Soc. J. 21: 600 (1974).

6. Dobkin, A.B., Eamkaow, S., \& Caruso, F.S. Double-blind comparison of butorphanol and pentazocine in patients with severe post-operative pain. Clin. Pharmacol. Ther. Vol. 18, No. 5, Part 1, pp. 547, November (1975).

7. Monkovic, I. Synthetic 14-hydroxymorphinan narcotic antagonists. Iowa City, Iowa, ACS Division of Medicinal Chemistry, Abstracts of 13th National Medicinal Chemistry Symposium (1972). 
8. Monkovic, I., Conway, T.T., Wang, H., Perron, Y.G., Pachter, I.J., \& Belleau, B Total synthesis and pharmacological activities of N-substituted 3, 14-dihydroxymorphinans. J. Am, Chem. Soc. 95: 7910 (1973).

9. Gordon, M., Pircio, A.W., Caruso, F.S., \& Pachter, I.J. Approaches to the problem of opiate abuse. Report of the Committee on Problems of Druge Dependence (1974).

10. Pircio, A.W., Gylys, J.A., Cavanagh, R.L., Buyniski, J.P., \& Bierwagen, M.E. Phamacology of butorphanol, a 3, 14-dihydroxymorphinan narcotic antagonist analgesic. Arch. Int. Pharmacodyn. Therap. 220: No. 2, 231-257 (1976).

11. Cavanagh, R.L., Gylys, J.A., \& Bierwagen, M.E. Antitussive properties of butorphanol. Arch. Int. Pharmacodyn. Therp., 220, No. 2, 258-267 (1976).

12. Swain, H.H., Villarreal, J.E., \& Seevers, M.H. Evaluation of new compounds for morphine-like physical dependence in the rhesus monkey. Report of the Committee on Problems of Drug Dependence, Addendum, p. 695 (1973).

13. Jasinski, D.R., Griffith, J.D., Pevnick, J.S., \& Clark, S.C. Progress reports on studies from the Clinical Pharmacology Section of the Addiction Research Center. Proceedings: Problems of Drug Dependence pp. 136 (1975).

14. FinNey, D.J. Statistical method in biological assay. 2nd ed. New York, Hafner Publishing Company (1964).

15. McArthur, J.W., Ulfelder, H., \& Finney, D.J. A flexible computer program for the composite analysis of symmetrical and asymmetrical biological assays of parallel-line type. J. Pharmacol. Exp. Ther. 153: 573 (1966)

16. Duncan, D.B. Multiple-range and multiple-F tests. Biometrics $11: 1$ (1955).

17. Duncan, D.B. A Bayesian approach to multiple comparisons. Technometrics $7: 171$ (1965).

18. Cramer, S.G. \& Swanson, M.R. An evaluation of ten pairwise multiple comparison procedures by Monte Carlo methods. J. Am. Statist. Assoc. 68: 66 (1973).

19. Goodman, L.W. \& Gilman, A. The pharmacological basis of therapeutics. 5th ed. p. 256 (1975).

20. BeEcher, H.K. Measurement of subjective responses. New York, Oxford University Press (1959)

21. Lasagna, L., Mostellen, F., von Felsinger, J.M., \& Beecher, H.K. A study of the placebo response. Am. J. Med. 16: 770 (1954).

22. Beecher, H.K. The measurement of pain in man. A re-inspection of the work of the Harvard Group, in Soulairoe, A., Cahn, J., and Charpentier, J., editors: Pain, Proceedings of the International Symposium on Pain, Paris, France (1967).

23. Lasagna, L. The clinical measurement of pain. Ann. N.Y. Acad. Sci. 28: 37 (1960).

24. Foldes, F.F., Nagashima, H., Karamanian, A.V., Hadnay, P., Malovany, R., Koerneh, S. \& ANG, M. Double-blind comparison of the respiratory and circulatory effects of intravenous butorphanol and morphine. Proceedings of the 1975 Committee on Problems of Drug Dependence, Washington, D.C., pp. 373-390 (May 1975).

25. Conssen, G., Tavakol, M., \& Caruso, F.S. Butorphanol and morphine: a double-blind comparison of the parenteral analgesic activity. Anesthesia and Analgesia (in press). 